\title{
SISTEM PAKAR MENDIAGNOSA PENYAKIT FLU BURUNG SECARA ONLINE DENGAN METODE FORWARD CHAINING
}

\author{
Arif Kurniawan \\ Program Studi Informatika \\ Fakultas Teknik Universitas Muhammadiyah Tangerang \\ J1. Perintis Kemerdekaan 1/33 Cikokol Kota Tangerang \\ arif.afk@umt.ac.id
}

\begin{abstract}
An expert system can be defined as a computer software that has a knowledge base for a particular domain and uses inference reasoning resembling an expert in solving a problem. Expert System to diagnose bird flu disease to discuss about how to create an expert system application that if able to diagnose bird flu disease and provide solutions of the disease. Where the expert system when associated with the ability of doctors in the early mediagnosa patient health conditions, can be created a computer system that is tasked to know and analyze the symptoms of illness suffered by patients to then provide direct advice to these patients. Inference technique that is done is forward tracking (forward chaining) with the method of search (Best First Search).
\end{abstract}

Keywords : Expert System, Bird Flu Disease, Forward Chaining, Best First Search

\section{PENDAHULUAN}

A. Latar Belakang Permasalahan

Dewasa ini perkembangan teknologi informasi telah mengalami perkembangan yang demikian pesat dimana banyak terlahir inovasi dan aplikasi teknologi bernilai tepat guna bagi semua kalangan untuk dapat memanfaatkannya secara optimal. Pemanfaatan teknologi informasi memerlukan perencanaan sistem yang matang agar dapat memberikan solusi pemecahan masalah yang tepat, cepat dan akurat. Sistem informasi berbasis website merupakan inovasi yang sangat baik untuk diterapkan pada bidang pendidikan, perdagangan, industri, maupun kedokteran.

Saat ini perkembangan sistem informasi yang berbasis web dimanfaatkan sebagai sarana peningkatan informasi dihampir semua bidang, baik bidang perdagangan, industri, pendidikan maupun kesehatan. Dengan adanya sistem berbasis aturan untuk mendiagnosa penyakit flu burung diharapkan akan pencarian informasi tentang penyakit flu burung untuk masyarakat yang belum begitu memahami tentang gejala-gejala penyakit flu burung dan juga mempermudah suatu pekerjaan seperti halnya pengolahan data lebih cepat, keputusan yang akan diambil lebih tepat, menghemat waktu yang dibutuhkan.

Selain itu, sistem informasi yang berbasis web juga dapat menjadi sumber sarana informasi yang dapat diakses oleh pengguna internet yang semakin lama semakin luas dan memberikan informasi yang dibutuhkan oleh masyarakat tentang penyakit flu burung, serta gejala dan pengobatannya. Sistem yang memberikan informasi mengenai penyakit flu burung, penyebab dan penanggulangannya menggunakan metode "Forward Chaning".

\section{B. Tujuan Penelitian}

Tujuan dari penelitian ini adalah untuk membantu masyarakat dalam penanggulangan penyakit flu burung (H5N1) dengan memanfaatkan internet sebagai sarana informasinya dan menggunakan metode "Forward Chaining" sebagai suatu sistem pakar untuk mengolah informasi menjadi suatu keputusan.

\section{TINJAUAN PUSTAKA}

\section{A. Konsep Dasar Sistem Pakar}

Menurut Arhami "sistem pakar (expert system) sendiri merupakan paket perangkat lunak atau paket program komputer yang ditujukan sebagai penyedia nasihat dan sarana bantu dalam memecahkan masalah di bidang-bidang spesialisasi tertentu seperti sains, perekayasaan, matematika, kedokteran, pendidikan dan sebagainya. Sistem pakar merupakan merupakan subset dari Artificial Intelegence".

Perkembangan teknologi sistem pakar sangat kuat dipengaruhi oleh ilmu kognitif dan matematika, seperti cara manusia menyelesaikan masalah dan landasan formal yang ada khususnya logika dan penalaran. Production Rules sebagai mekanisme 
representasi, tipe Rules IF ... THEN yang merupakan representasi yang penalaran manusia dan dapat dimanipulasi oleh komputer. Kesesuaian antara potongan-potongan pengetahuan dapat digunakan untuk manusia dan komputer. Rules dapat digunakan untuk formulasi suati teori dari pemrosesan informasi manusia. Seperti kita ketahui memori manusia dapat dibagi menjadi tiga (3), yaitu Sensory Memory, Short Term Memory (STM),

Pada dasarnya sistem pakar diterapkan untuk mendukung aktivitas pemecahan masalah. Beberapa aktivitas pemecahan masalah yang dimaksud seperti (Lestari, 2012):

1. Interpretasi. Membuat kesimpulan atau deskripsi dari sekumpulan data mentah. Pengambilan keputusan dari hasil observasi, termasuk pengenalan ucapan, analisis citra, interpretasi sinyal, dll.

2. Prediksi. Memproyeksikan akibat-akibat yang dimungkinkan dari situasi-situasi tertentu. Contoh: prediksi demografi, prediksi ekonomi, dll.

3. Diagnosis. Menentukan sebab malfungsi dalam situasi kompleks yang didasarkan pada gejalagejala yang teramati diagnosis medis, elektronis, mekanis, dll.

4. Perancangan (desain). Menentukan konfigurasi komponen-komponen sistem yang cocok dengan tujuan-tujuan kinerja tertentu yang memenuhi kendala-kendala tertentu. Contoh: perancangan layout sirkuit, bangunan.

5. Perencanaan. Merencanakan serangkaian tindakan yang akan dapat mencapai sejumlah tujuan dengan kondisi awal tertentu. Contoh: perencanaan keuangan, militer, dll.

6. Monitoring. Membandingkan hasil pengamatan dengan kondisi yang diharapkan. Contoh: computer aided monitoring system.

7. Debugging. Menentukan dan menginterpretasikan cara-cara untuk mengatasi malfungsi. Contoh: memberikan resep obat terhadap kegagalan.

8. Instruksi. Mendeteksi dan mengoreksi defisiensi dalam pemahaman domain subjek. Contoh: melakukan instruksi untuk diagnosis dan debugging.

9. Kontrol. Mengatur tingkah laku suatu environment yang kompleks. Contoh: melakukan kontrol terhadap interpretasi, prediksi, perbaikan dan monitoring kelakukan sistem.

\section{B. Komponen Utama Sistem Pakar}

Komponen-komponen yang terdapat dalam arsitektur/struktur sistem pakar pada gambar di atas dijelaskan sebagai berikut:
1. Antarmuka Pengguna (User Interface)

Antarmuka merupakan mekanisme yang digunakan oleh pengguna dan sistem pakar untuk berkomunikasi. Antarmuka menerima informasi dari pemakai dan mengubahnya ke dalam bentuk yang dapat diterima oleh sistem. Selain itu antarmuka menerima dari sistem dan menyajikannya ke dalam bentuk yang dapat dimengerti oleh pemakai.

2. Basis Pengetahuan

Basis pengetahuan mengandung pengetahuan untuk pemahaman, formulasi, dan penyelesaian masalah.

3. Akuisisi Pengetahuan (Knowledge Acquisition) Akuisisi pengetahuan adalah akumulasi, transfer, dan transformasi keahlian dalam menyelesaikan masalah dari sumber pengetahuan ke dalam program komputer. Dalam tahap ini knowledge engineer berusaha menyerap pengetahuan untuk selanjutnya ditransfer ke dalam basis pengetahuan. Pengetahuan diperoleh dari pakar, dilengkapi dengan buku, basis data, laporan penelitian, dan pengalaman pemakai.

4. Mesin/Motor Inferensi (Inference Engine)

Komponen ini mengandung mekanisme pola pikir dan penalaran yang digunakan oleh pakar dalam menyelesaikan suatu masalah. Mesin inferensi adalah program komputer yang memberikan metodologi untuk penalaran tentang informasi yang ada dalam basis pengetahuan dan dalam workplace, dan untuk memformulasikan kesimpulan.

5. Workplace/Blackboard

Workplace merupakan area dari sekumpulan memori kerja (working memory), digunakan untuk merekam kejadian yang sedang berlangsung termasuk keputusan sementara.

6. Fasilitas Penjelasan

Fasilitas penjelasan adalah komponen tambahan yang akan meningkatkan kemampuan sistem pakar, digunakan untuk melacak respon dan memberikan penjelasan tentang kelakuan sistem pakar secara interaktif melalui pertanyaan.

7. Perbaikan Pengetahuan

Pakar memiliki kemampuan untuk menganalisis dan meningkatkan kinerjanya serta kemampuan untuk belajar dari kinerjanya. Kemampuan tersebut adalah penting dalam pembelajaran terkomputerisasi, sehingga program akan mampu menganalisis penyebab kesuksesan dan kegagalan yang dialaminya dan juga mengevaluasi apakah pengetahuan-pengetahuan yang ada masih cocok untuk digunakan di masa mendatang. 


\section{Struktur Sistem Pakar}

Sistem pakar terdiri dari dua bagian pokok, yaitu: lingkungan pengembangan (development environment) dan lingkungan konsultasi (consultation environment). Lingkungan pengembangan digunakan sebagai pembangun sistem pakar baik dari segi pembangunan komponen maupun basis pengetahuan. Lingkungan konsultasi digunakan oleh seseorang yang bukan ahli untuk berkonsultasi [2].

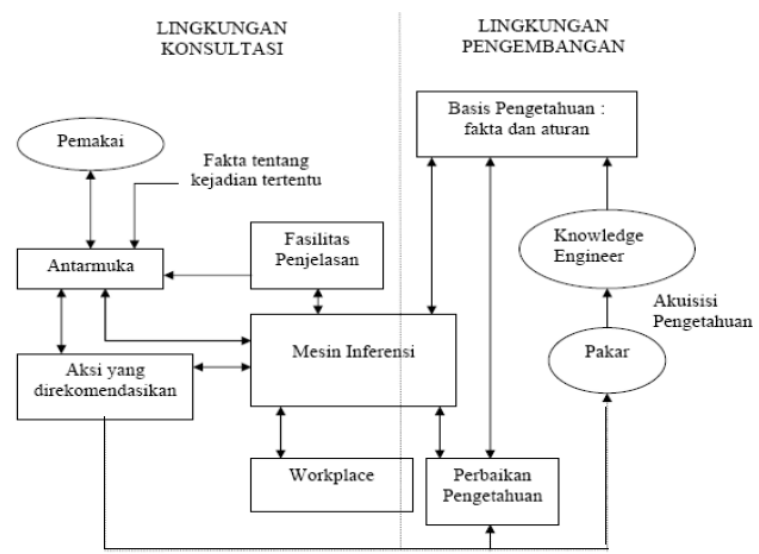

Gambar 1 Struktur Sistem Pakar

\section{Forward Chaining}

Menurut Arhami, "Forward chaining disebut juga penalaran dari bawah ke atas karena penalaran dari fakta pada level bawah menuju konklusi pada level atas didasarkan pada fakta". Penalaran dari bawah ke atas dalam suatu sistem pakar dapat disamakan untuk pemgrograman konvensional dari bawah ke atas. Fakta merupakan satuan dasar dari paradigma berbasis pengetahuan karena mereka tidak dapat diuraikan ke dalam satuan paling kecil yang mempunyai makna.

Inference Engine akan mencocokan fakta atau statement dalam Knowledge Base dengan situasi yang dinyatakan dalam rules bagian $I F$. Jika fakta yang ada dalam Knowledge Base sudah sesuai dengan kaidah $I F$, maka rule itu distimulasi dan rule berikutnya diuji. Proses pengujian rule satu demi satu berlanjut sampai satu putaran lengkap melalui seluruh perangkat rule.

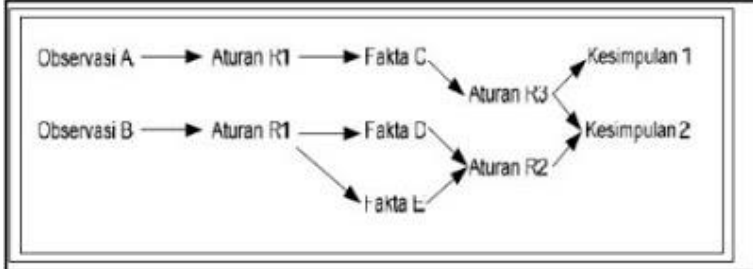

Gambar 2 Penalaran Forward Chaining

\section{E. Penyebab Flu Burung}

Penyebab flu bururng (Bird Flu/Avian Influenza) adalah virus influenza tipe A. Virus Influenza termasuk Famil Orthomixoviridae. Virus influenza tipe A dapat berubah-ubah bentuk (drift,sShift) dan dapat menyebabkan epidemi dan pandemi. Berdasarkan sub tipenya terdiri dari Hemaglutinin $(H)$ dan Neuramidase $(N)$. kedua huruf ini digunakan sebagai identifikasi kode subtipe flu burung yang banyak jenisnya.

Jenis virus yang terdapat pada manusia adalah H1N1, H2N2, H3N3, H5N1, H9N2, H1N2, H7N7. Sedangkan pada binatang H1-H5 dan N1-N9. Strain yang sangat Virulen / ganas dan menyebabkan flu burung adalah dari tipe A H5N1. Virus tersebut dapat bertahan hidup diair sampai 4 hari pada suhu $22^{\circ} \mathrm{C}$ dan lebih dari 30 hari pada suhu $0^{\circ} \mathrm{C}$. Virus akan mati pada pemanasan $60^{\circ} \mathrm{C}$ selama 30 menit atau $56^{\circ} \mathrm{C}$ selama 3 jam dan detergent, desinfektan misalnya formalin, serta cairan yang mengandung lodin.

Flu burung menular dari unggas ke unggas, dan dari unggas ke manusia. Penularan flu burung pada manusia diantaranya bisa melalui air liur, lendir dari hidung dan faces (tinja) atau debu yang dicemari tinjanya. Penyakit ini dapat menular melalui udara yang tercemar oleh virud $H 5 N 1$ yang berasal dari kotoran atau sekreta burung/unggas yang menderita flu burung.

Flu burung memiliki gejala yang bervariasi, pada kasus yang sangat ganas (Akut) ditandai dengan kematian tanpa disertai gejala klinis. Hewan tampak sehat tetapi tiba-tiba mati. Namun pada umumnya gejala yang ditimbulkan oleh infeksi virus flu burung akan menunjukan gejala-gejala, antara lain :

1. Kasus Suspek (tersangka)

Kasus Suspek adalah kategori dari penyakit flu burung yang paling ringan. Biasanya seseorang yang menderita Infeksi Saluran Pernapasan Akut (ISPA) dengan gejala: demam (hingga suhu badan $>39^{\circ} \mathrm{C}$ ), batuk, sakit tenggorokan dan hidung berhingus.

2. Kasus Probable

Kasus Probable adalah kasus suspek dengan salah satu keadaan sebagai berikut:

a. 7 hari (seminggu) terakhir sebelum sakit, mengunjungi peternakan yang sedang terjangkit flu burung.

b. 7 hari (seminggu) sebelum sakit, kontak dengan unggas sakit atau mati.

c. Cluster (kelompok) radang paru berat (pneumonia berat)

d. Pemeriksaan darah : Leukosit < 5000, Limfositopenia dan Trombositopenia. 
e. HAsil pemeriksaan dengan $\mathrm{HI}$ tes positif pada spesimen tunggal atau kenaikan titer sepasang spesimen kurang dari 4 kali.

3. Kasus Konfirmasi

Kasus Konfirmasi adalah kasus suspek atau "Probable" disertai oleh salah satu hasil pemeriksaan laboratorium :

a. Kultur virus influenza A / H5N1 positif

b. RT-PCR influenza (H5) positif

c. Peningkatan titer antibodi $\mathrm{H} 5$ sebesar 4 kali atau lebih pada pemeriksaan spesimen kedua dengan Mikro Neutralization tes

d. IF A tes positif (+) dengan antibodi Monoklonal / influenza A/H5

4. Gejala Klinis / Observasi

Gejala Klinis yang ditemui seperti gejala pada umumnya, yaitu : demam, sakit tenggorokan, batuk, beringus, nyeri otot, sakit kepala, dan lemas. Dalam waktu singkat penyakit ini dapat menjadi lebih berat yaitu peradangan di paruparu (pneumonia), dan apabila tidak cepat ditangani dengan baik dapat menyebabkan kematian. Masa Inkubasi flu bururng dapat dibedakan juga pada manusia dan unggas :

a. Pada unggas : 1 minggu

b. Pada manusia : 1-3 hari, masa infeksi 1 hari sebelum sampai 3-5 hari sesudah timbul gejala. Pada anak sampai 2 hari.

\section{ANALISIS DAN PEMBAHASAN}

A. Basis Pengatahuan

Isi dari basis pengetahuan berupa fakta-fakta dan aturan-aturan yang dipakai oleh beberapa pakar dengan dilandasi pengetahuan yang diperoleh dari pengalaman beberapa pakar. Untuk merepresentasikan pengetahuan digunakan sebuah metode kaidah produksi yang biasanya dituliskan dalam bentuk JIKA-MAKA (IF-THEN). Fakta-fakta atau aturan-aturan yang digunakan dalam sistem pakar ini adalah :

Rule 1: Jika Demam tinggi lebih dari $39^{\circ}$ Celcius dan keluar lendir bening pada hidung dan batuk dan sakit tenggorokan dan nafsu makan berkurang dan mual-mual dan muntah dan diare dan infeksi selaput mata dan sesak nafas dan radang paru-paru dan sakit kepala dan badan lemes dan nyeri otot maka Gejala Mirirp Flu Burung

Rule 2: Jika keluar lendir pada hidung dan batuk dan sakit tenggorokan dan nafsu makan berkurang dan sakit kepala dan meriang dan badan lemes dan nyeri otot maka Gejala Mirip Flu Biasa
Rule 3 : Jika mual-mual dan muntah dan sakit kepala dan badan lemes maka Gejala Mirip Maag

\section{B. Mesin Inference}

Didalam sistem pakar ini teknik inferensi yang digunakan adalah pelacakan dan pencarian. Teknik pelacakan yang digunakan adalah teknik pelacakan kedepan (Forward Chaining), sedangkan untuk pencarian keputusan dari setiap permasalahan digunakan metode pencarian Best First Search yaitu pencarian yang menggabungkan dua metode pencarian yang ada, yaitu: metode Breadth First Search dan Depth First Search. Dari fakta-fakta dan aturan-aturan diatas dapat digambarkan dalam pohon keputusan sebagai berikut:

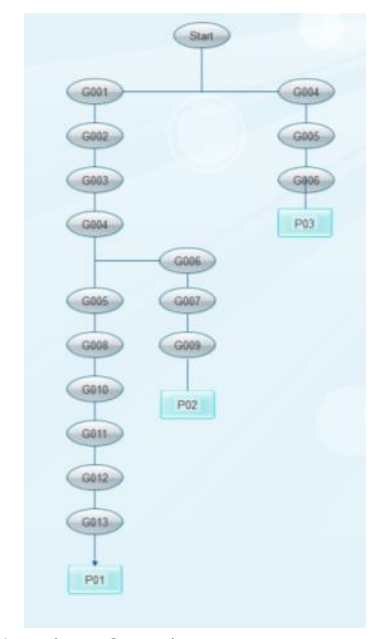

Gambar 3 Pohon Keputusan

Penjelasan dari kode-kode pada pohon keputusan: G001 : Sakit Kepala

G002 : Keluar lendir bening dari hidung

G003 : Nafsu makan berkurang

G004 : Demam dengan suhu badan $>39^{\circ} \mathrm{C}$

G005 : Mual dan muntah-muntah

G006 : Batuk dan sakit tenggorokan

G007 : Badan lemas

G008 : Nyeri otot dan sendi

G009 : Meriang

G010 : Diare

G011 : Radang paru-paru

G012 : Infeksi selaput mata

G013 : Sesak nafas

Data dari identifikasi dan solusi yang dialami yaitu:

P001 : Gejala mirip flu burung

Solusi : 1. Oksigenisasi bila terjadi sesak napas 2. Hidrasi dengan pemberian cairan parental (infus). 
3. Pemberian obat anti virus oseltamivir $75 \mathrm{mg}$ dosis tunggal selama 7 hari (seminggu)

4. Amantadin diberikan pada awal infeksi, sedapat mungkin dalam waktu 48 jam pertama selama 3-5 hari dengan dosis $5 \mathrm{mg} / \mathrm{kg}$ BB perhari dibagi dalam 2 dosis. Bila berat badan lebih dari $45 \mathrm{~kg}$ diberikan $100 \mathrm{mg} 2$ kali sehari

5. Disarankan periksakan diri ke dokter untuk tindakan lebih lanjut dan dilakukan pemeriksaan pada darah anda.

P002 : Gejala mirip flu burung

Solusi : Istirahat yang cukup dan periksakan ke dokter terdekat

P003 : Maag

Solusi : Makan jangan telat dan jangan terlalu kenyang juga jangan lupa meminum obat maag, jika sekiranya perlu pemeriksaan lebih lanjut.

Urutan prosedure rancangan program secara detail bisa dilihat pada gambar flowchart dibawah ini:

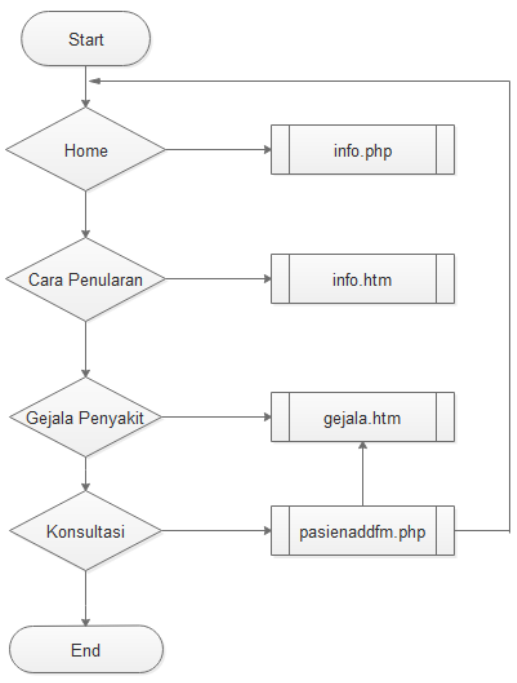

Gambar 4 Flowchart Form Index

\section{Rancangan antarmuka Form Index}

Halaman ini berfungsi sebagai halaman depan/homepage. Didalam halaman ini terdiri dari menu pilihan yang dapat dilihat oleh pengunjung. Untuk listing index.php dapat dilihat pada daftar listing A1 gambar dari halaman index.php ini adalah:

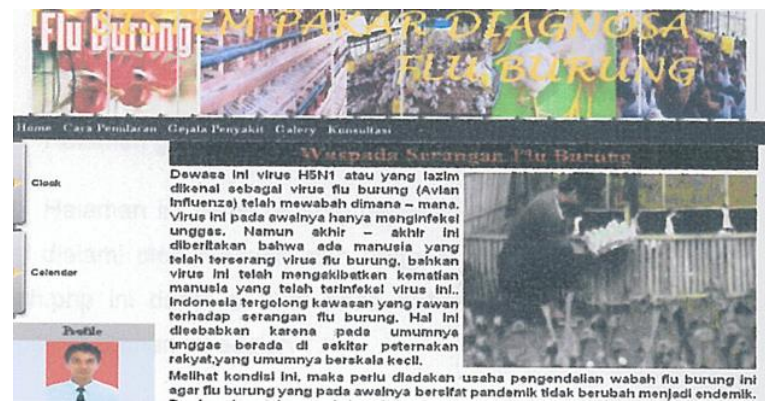

Gambar 5 Halaman Home/Index

D. Rancangan antarmuka Form Daftar Konsultasi Halaman ini digunakan untuk melakukan pendaftaran bagi pasien yang akan melakukan konsultasi dengan sistem pakar flu burung ini. Berikut tampilan dari halaman Daftar Konsultasi adalah:

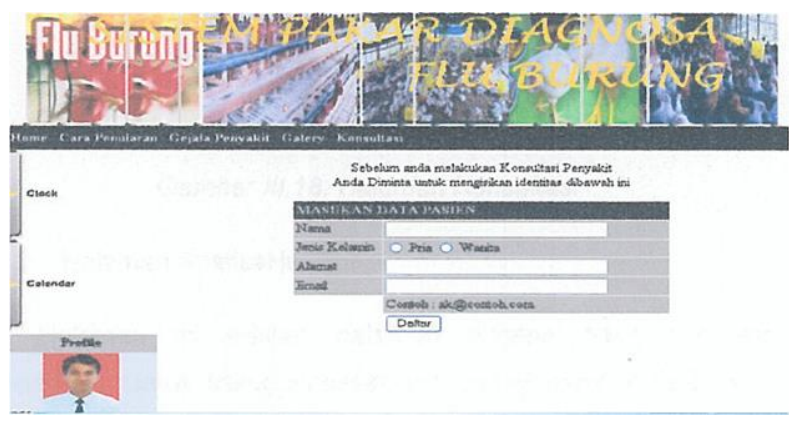

Gambar 6 Form Daftar Konsultasi

\section{E. Rancangan antarmuka Form Konsultasi}

Halaman ini digunakan untuk menjawab semua pertanyaan yang diberikan oleh sistem kepada pasien. Berikut rancangan antarmuka dari Form Konsultasi:

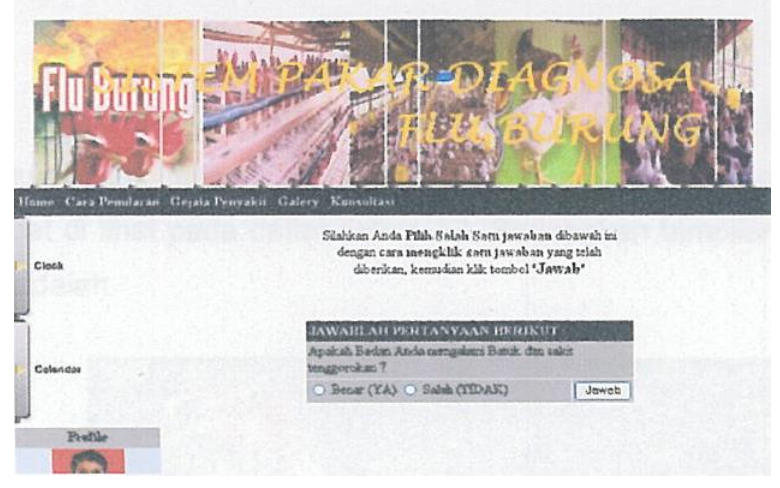

Gambar 7 Form Konsultasi 


\section{F. Rancangan antarmuka Form Hasil Analisa}

Halaman ini digunakan untuk menampilkan hasil konsultasi pasien dengna aplikasi sistem pakar dimana pasien telah selesai menjawab semua pertanyaan yang diberikan oleh sistem pakar tersebut. Berikut gambar rancangan dari Form Hasil Analisa:

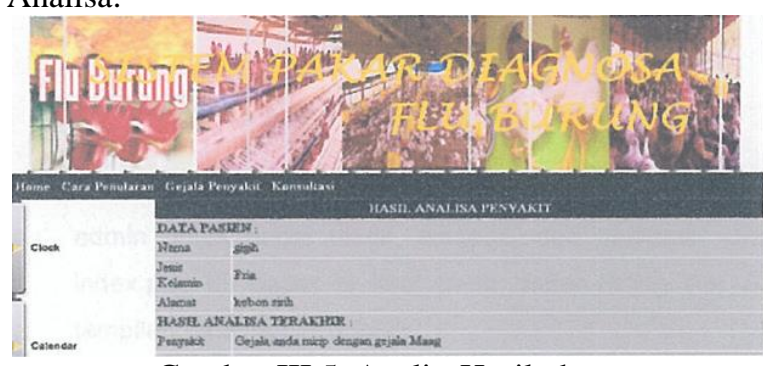

Gambar III.5. AnalisaHasil.php

\section{G. Rancangan Sistem}

1. Business Actor

Business Actor mendefinisikan entitas eksternal dan orang yang berinteraksi dengan sistem bisnis. Sebuah Business Actor dapat berupa orang, namun sebuah sistem informasi yang berinteraksi dengan sistem bisnis juga bisa berperan segabai sebuah Business Actor.

Dalam sistem pakar ini hanya terdapat 2 buah business actor, yaitu:

a. User, yaitu orang yang akan melakukan konsultasi (pasien) sebekum melakukan konsultasi user terlebih dahulu harus mengisi data diri dan kemudian baru dilanjutkan dengan berkonsultasi dengan cara menjawab pertanyaanpertanyaan yang diajukan oleh sistem berupa gejala-gejala penyakit yang mungkin terjadi pada badan user, kemudian akan diberikan kesimpulan akhir berupa hasil analisa.

b. Admin, yaitu bagian yang memiliki has akses penuh dalam sistem tersebut untuk mengelola informasi dan semua data yang ada didalam aplikasi sistem pakar tersebut.

\section{Business Use-Case}

Business use-case digunakan untuk menyatakan fungsional yang disediakan oleh suatu organisasi secara keseluruhan dan digunakan secara intensif untuk menghimpun konteks sistem dan membentuk dasar pembuatan use-case.

Kegiatan yang digambarkan oleh Business UseCase adalah:

a. Login : Kegiatan ini dilakukan untuk dapat masuk kedalam ruang admin,agar dapat mengelola data informasi yang terdapat diruang pakar. b. Manajemen Data : Kegiatan ini dilakukan untuk mengelola data seperti menambah, menghapus, dan merubah data pakar.

c. Validasi Data : Kegiatan ini hanya dapat dilakukan oleh admin yaitu memvalidasi data-data inputan yang nantinya akan disimpan kedalam database.

\section{Business Object Model}

Merupakan penjelasan lebih lanjut atau rinci dari diagram use-case yang bertujuan untuk mengetahui proses dan interaksi yang terjadi dalam setiap prosesnya. Berikut ini merupakan kegiatan dalam website sistem pakar yang digambarkan dalam Business Object Model.

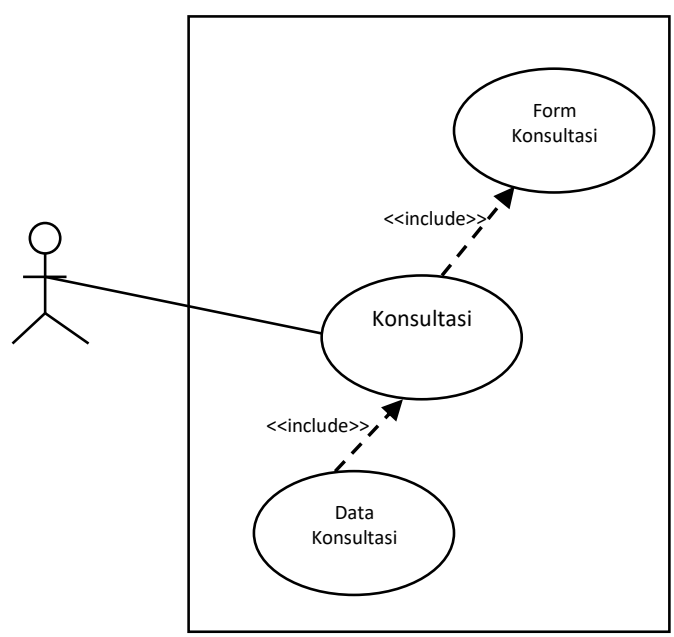

Gambar IV.1. use-case Konsultasi

Tabel 1 Use-case Diagram Konsultasi

\begin{tabular}{|l|l|}
\hline Use case & \multicolumn{1}{|c|}{ Melihat Gejala flu burung } \\
\hline Bescription & $\begin{array}{l}\text { Use case ini memungkinkan } \text { user } \\
\text { untuk membuka website sistem } \\
\text { pakar dan melakukan konsultasi }\end{array}$ \\
\hline Actor & User, Admin \\
\hline Precondition & $\begin{array}{l}\text { User menggunakan } \text { browser internet } \\
\text { untuk melakukan konsultasi }\end{array}$ \\
\hline Main Flow & $\begin{array}{l}\text { Use case ini dimulai saat seorang } \\
\text { user ingin melakukan konsultasi. } \\
\text { Pertama kali pengunjung langsung } \\
\text { menuju halaman home/index, } \\
\text { kemudian pengunjung dapat memilih } \\
\text { menu atau link konsultasi yang } \\
\text { disediakan pada website sistem pakar }\end{array}$ \\
\hline $\begin{array}{l}\text { Alternative } \\
\text { Flow }\end{array}$ & $\begin{array}{l}\text { Jika } \text { user memilih menu konsultasi } \\
\text { maka } \text { user dapat melakukan } \\
\text { konsultasi dan mendapatkan hasil } \\
\text { dari analisa tersebut }\end{array}$ \\
\hline
\end{tabular}




\begin{tabular}{|l|l|}
\hline Post & Jika user berhasil melakukan \\
& $\begin{array}{l}\text { langkah tersebut maka hasil akhir } \\
\text { yang akan diperoleh adalah hasil } \\
\text { analisa serta solusi atas penyakit } \\
\text { yang diderita }\end{array}$ \\
\hline
\end{tabular}

\section{KESIMPULAN}

Dari hasil penelitian ini memiliki keuntungan yang bisa diambil dengan penerapan sistem pakar berbasis website ialah dapat meminimalisir waktu, biaya juga efektifitas. Diharapakan para pengguna aplikasi website ini terbantu dan mempermudah untuk dapat informasi mengenai penyakit flu burung.

Sistem ini akan lebih baik dan sempurna jika didukung dengan hasil pemeriksaan lebih lanjut ke laboratorium, baik itu berupa foto rontgen dan/atau hasil pemeriksaan darah.

Tentu saja penelitian ini masih jauh dari kata sempurna, oleh karena itu diharapkan untuk saran dan kritik yang bersifat membangun sangat diperlukan untuk memperbaiki dan mengembangkan penelitian ini dimasa yang akan datang.

\section{DAFTAR PUSTAKA}

[1] Arhami, Muhammad. 2005. Konsep Dasar Sistem Pakar. Penerbit Andi. Yogyakarta

[2] Kusumadewi, Sri. 2003. Artificial Intelligence (Teknik dan Aplikasinya). Graha Ilmu. Yogyakarta.

[3] Lestari D. 2012. Jurnal: Definisi sistem pakar. Arsip Teknik Informatika UMMI.

[4] Turban, Efraim. 1995. Decision Support System and Expert System. Prentice Hall International, New Jersey.

[5] Kusrini dan Emha Taufiq Luthfi. 2009. Algoritma Data Mining. Penerbit Andi Offset, Yogyakarta. 